\begin{tabular}{c} 
International Journal of Medicine, 5(1)(2016) $1-4$ \\
International Journal of Medicine \\
WPC \\
Website: $\begin{array}{c}\text { www.sciencepubco.com/index.php/IJM } \\
\text { doi: } 10.14419 / \text { ijm.v5il.6827 } \\
\text { Research paper }\end{array}$ \\
\hline
\end{tabular}

\title{
Health day at the university of Namibia 2014 : A community service
}

\author{
Taimi Nauiseb *, Joan. M Kloppers \\ Private bag 13301340 Mandume Ndemufayo Ave, Pionierspark Windhoek Namibia, \\ School of Nursing and Public Health, University of Namibia \\ *Corresponding authorE-mail: tnauiseb @ unam.na
}

\begin{abstract}
Although there are many 'health days' to promote important public health issues, many of which are supported by different institutions. Global public health campaigns offer great potential to raise awareness and understanding about health issues. There are many world days observed throughout the year related to specific health issues or conditions.

The School of Public Health conducted yearly a health day in the beginning of March or April of each year. According to Clinicians handbook (1998) explains check -up as a clinical preventive services usually delivered by primary health care clinicians to persons with no signs and symptoms of illness as part of a routine health care process. Central to the periodic health examination.
\end{abstract}

Keywords: Health day; Awareness raising; Clinical preventative services; Health activities; Health examination; Health facility;

\section{Introduction}

Health days are important to ensure that the students function in an optimal holistic approach throughout their study life, being it physical, social, psychological and economical. It is said that a healthy body host a healthy mind and spirit. This survey will raise awareness to students to know the importance of once health.

\section{Specific objectives}

To assess whether students do take care of their own health by determining how often they go for blood pressure, sugar test, weight and length checkup.

To explore how often students visit the health facility on the campus.

To determine whether students utilized the health facility on campus.

\section{Method}

A research design is an outline, plan or strategy specifying the procedure to be used in seeking an answer to the research question and specifies how to collect and analyze data (Christensen, 2004).

A small mini-survey has been conducted on all those visiting the library on the specific date for the health day.

\subsection{Ethical issues}

The following ethical issues were followed during the study to better protect the rights of the research respondents.
To adhere to this principle the researcher did not coerce participants to be part of the study. The researcher provided needed information regarding the study and ensured that respondents understood the objectives of the study to which enable them to participate voluntarily. The participants were explained to withdraw anytime from the study if they so wish.

Principle of beneficence.

The researcher did ensure that participants were protected from harm. The questions asked were not sensitive and participants were monitored throughout the process of questionnaires for any sign of discomfort. Respondents were explained the choice of withdrawing from the study or stopping if they feel uncomfortable.

Principle of Justice.

The participants were assured that collected information would not be made available to anyone who is not directly involved in the survey. The reported findings will be shared with concerned parties in such a way that the participants will remain anonymous.

\section{Results and discussion}

\subsection{Results}

The questionnaires consisted of a series of questions namely covering the aspects of: demographic information, general information on health aspects.

The total respondents who took part in the survey were 54 .

Principle of respect for persons. 


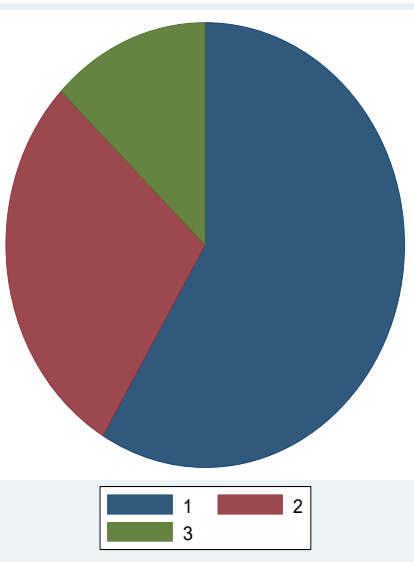

Fig 1: Age Categories of Respondents.

\begin{tabular}{llll}
\hline Color code numbering & Group & Total Number & Percentage \\
\hline 1 & $18-25$ years & 41 & $75.9 \%$ \\
2 & $26-35$ years & 10 & $18.5 \%$ \\
3 & 36 and above & 3 & $5.5 \%$ \\
\hline
\end{tabular}

The majority age group of respondents was between the age group 18-25 years who made out $75.9 \%$ of all respondents.

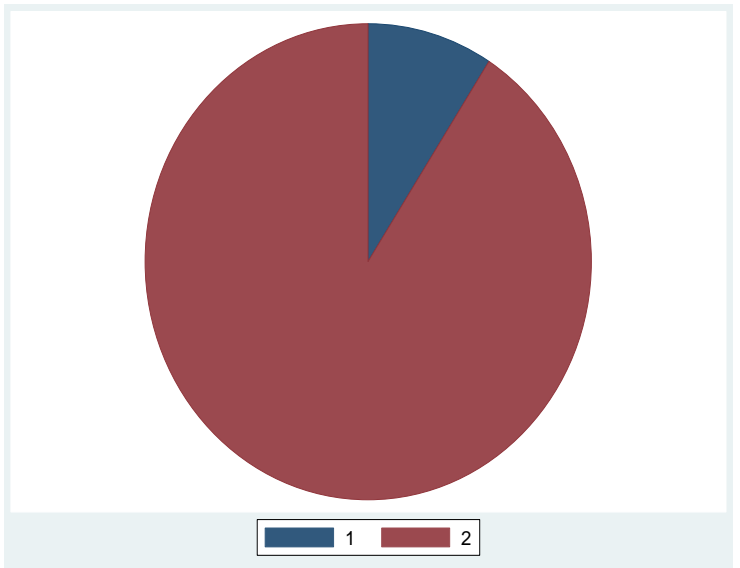

Fig. 2: Respondents Utilizing Clinic on Campus.

\begin{tabular}{llll}
\hline Color code numbering & Yes/No & Total Number & Percentage \\
\hline 1 & Yes & 9 & $17 \%$ \\
2 & No & 45 & $83 \%$ \\
\hline
\end{tabular}

The respondents not using the clinic appear to be the majority with $83 \%$, compare to those using the clinic with $17 \%$.

The reason why students don't use the clinic could be that the clinic has not been functioning because it was close down for renovation. Students went to other clinics in the regions.

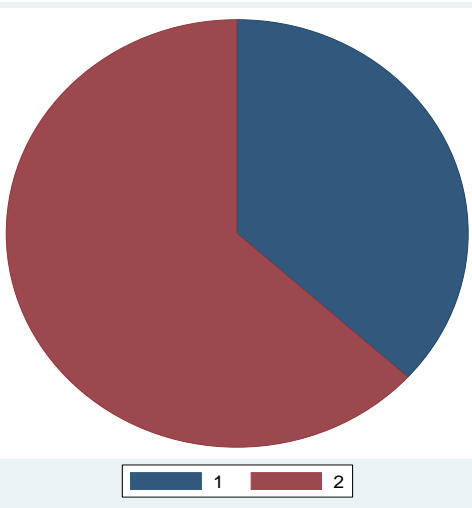

Fig. 3: Respondents Knowledge on Their Weight.

\begin{tabular}{llll}
\hline Color code numbering & Yes/No & Total Number & Percentage \\
\hline 1 & No & 25 & $46.2 \%$ \\
2 & Yes & 29 & $53.7 \%$ \\
\hline
\end{tabular}

$53.7 \%$ of the respondents were having knowledge of their weight, compare to only $46.2 \%$ who had no knowledge.

A cross sectional study was conducted to 540 students ranging in the age from 19-24 years in Northern China. The study revealed that $80.5 \%$ of students had a normal BMI and $16.6 \%$ of students were underweight with the prevalence of BMI $>30$ obesity being very low in this study.

Habits involving regular eating patterns as well as vegetables were reported (Sakamati, Toyama, Amamoto, Liu, and Shinfuka, 2005). A dietary survey of Japanese respondents revealed a low rate in regular eating patterns (Ministry of Health Labor and Welfare, Japan, 2004).

A study revealed that adequate breakfast habits might contribute to the appearance to develop obesity (Oritega, Redondo, Lopez-Sobaler, Quintas, Zamora, Andres, Encinas-Sotillos, 1996).

A number of researchers study revealed that women desire a thinner body while men desire a heavier physique and muscularity (Pope, Gruber, Manweth, Bureau, de Col, Jouvert and Hudson, 2000).

The percentage of children and adolescents who are overweight has doubled in the last 30 years and the prevalence of obesity and related mortality rates continue to rise in adults (Flegal, Caroll, Ogden \& Johnson, 2002).

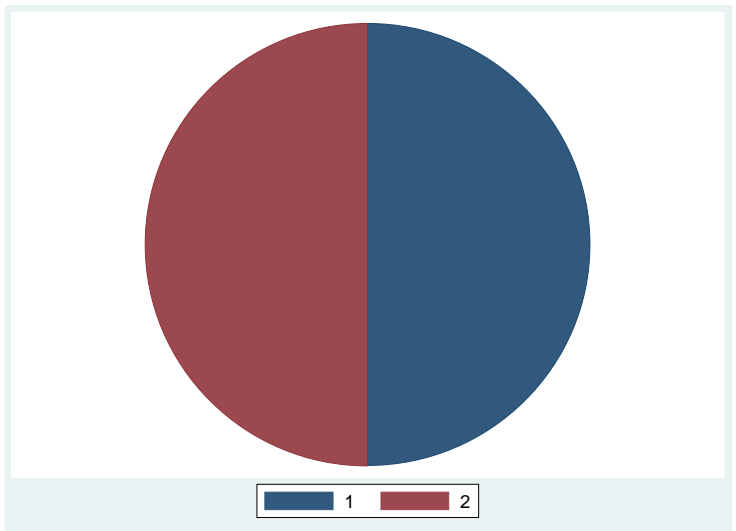

Fig. 4: Respondents Knowledge on Their Height.

\begin{tabular}{llll}
\hline Color code numbering & Yes/No & Total Number & Percentage \\
\hline 1 & Yes & 35 & $64.8 \%$ \\
2 & No & 19 & $35.1 \%$ \\
\hline
\end{tabular}

$64.8 \%$ of the respondents were having knowledge of their height, compare to only $35.1 \%$ who had no knowledge.

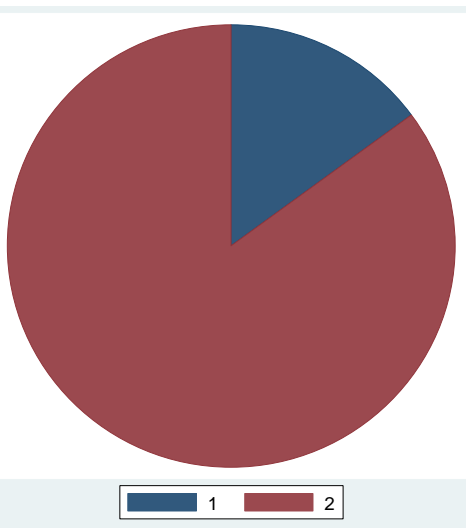

Fig. 5: Respondents Attending Regular BP- Check.

\begin{tabular}{llll}
\hline Color code numbering & Yes/No & Total Number & Percentage \\
\hline 1 & Yes & 14 & $25.9 \%$ \\
2 & No & 40 & $74 \%$ \\
\hline
\end{tabular}


$25.9 \%$ of the respondents went for regular blood pressure check, compare to only $74 . \%$ who were not going, forming the majority. Hypertension has the greatest risk factor for early morbidity and mortality caused by cardiovascular diseases (CD). Blood pressure (BP) is associated to a higher incidence of (CD) which are a problem for public health and are the main cause of death in most countries among adults Vason, Larson, Leip, Evans, O'Donnell\& Kannel, (2001).

A descriptive study was conducted among 667 undergraduate students from Lubango-, Angola to investigate the prevalence of hypertension. The findings was that $61.3 \%$ were between the age group 18-29 years old; prevalence of hypertension from 20.3 to $26.7 \%, 17.1 \%$ were overweight; $60.6 \%$ preferred salty food; $4.0 \%$ were smokers; $40.6 \%$ drank alcohol. The results of this study indicated that there was a need for orientation programs to inform the population on chronic diseases (Simao, Hayashida, dos Santos, Cesarino \& Nogueira, 2008).

Another study was conducted at the Makeree University on 183 under graduates; found that $35 \%$ were normal, $54 \%$ pre- hypertensive and $11 \%$ hypertensive Bimenya, Byarugaba, Kalungi, Mayito Mugabe, Makabayi, Ayebare, wanzira \& Muhame (2005).

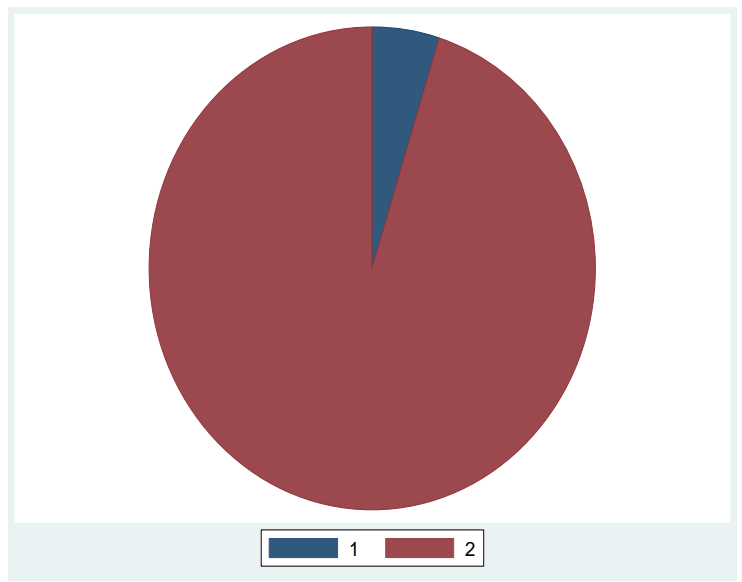

Fig. 6: Respondents Attending Regular Sugar Test.

\begin{tabular}{llll}
\hline Color code numbering & Yes/No & Total Number & Percentage \\
\hline 1 & Yes & 5 & $9.25 \%$ \\
2 & No & 49 & $90.7 \%$ \\
\hline
\end{tabular}

The majority $90.7 \%$ of the respondents were not attending regular sugar test, compare to only $9.5 \%$ who do attend.

Khan Gomathi, Shehnaz and Muttappallymyalil, 2012 conducted a study among 168 university students in Ajmanto to assess diabetes mellitus (DM). 25\% were overweight or obese and $27 \%$ exercised regularly. Regarding knowledge of DM, 70\% knew that high blood sugar levels are identified by family history. The study further revealed that the students' knowledge was not adequate.

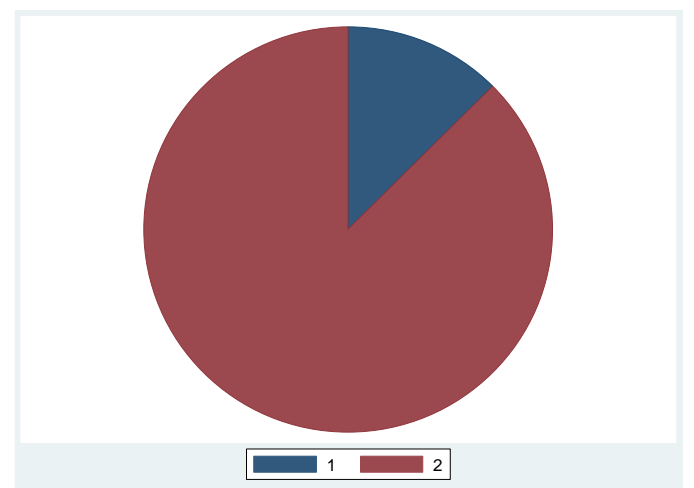

Fig. 7: Respondents Attending Regular Eye Test.

\begin{tabular}{llll}
\hline Color code numbering & Yes/No & Total Number & Percentage \\
\hline 1 & Yes & 12 & $22.2 \%$ \\
2 & No & 42 & $77.7 \%$ \\
\hline
\end{tabular}

$77.7 \%$ of the respondents were not attending regular eye test, compare to only $22.2 \%$ who attended.

Shantakumari, Eideeb, Sreedharan \& Gopal, (2014) conducted a study on 500 university students in Ajman. The study was undertaken to assess visual problems among students. The most visual problems reported among computer users were headache $-53 \%$; burning sensation in the eyes $54.8 \%$ tired eyes- $48 \%$.

Another study was conducted on 599 University students in New Zealand by Garner, Waghorne \& Anstice (1981). The study revealed that $33.2 \%$ of the participants wore spectacles or contact lenses and $27.1 \%$ never had a visual examination. A high proportion reporting visual problems and many had not sought advice.

Table 1: Health activities carried out during the health day.

\begin{tabular}{|c|c|c|c|c|c|c|}
\hline $\begin{array}{l}\text { Activi- } \\
\text { ties }\end{array}$ & $\begin{array}{l}\text { To- } \\
\text { tal }\end{array}$ & Male & $\begin{array}{l}\mathrm{Fe}- \\
\text { male }\end{array}$ & $\begin{array}{l}\text { Nor- } \\
\text { mal } \\
\text { find- } \\
\text { ings }\end{array}$ & $\begin{array}{l}\text { Abnor- } \\
\text { mal } \\
\text { Findings }\end{array}$ & $\begin{array}{l}\text { Interven- } \\
\text { tion }\end{array}$ \\
\hline $\begin{array}{l}\text { Neck } \\
\text { massage }\end{array}$ & 80 & 16 & 64 & All & Normal & None \\
\hline $\begin{array}{l}\text { Sugar } \\
\text { test }\end{array}$ & 110 & 32 & 78 & 107 & 3 & $\begin{array}{l}\text { Refer for } \\
\text { checkup at } \\
\text { clinic. }\end{array}$ \\
\hline $\begin{array}{l}\text { Blood } \\
\text { Pressure }\end{array}$ & 159 & 46 & 113 & 147 & 12 & $\begin{array}{l}\text { Refer for } \\
\text { check up } \\
\text { At clinic. }\end{array}$ \\
\hline $\begin{array}{l}\text { Eye } \\
\text { Test }\end{array}$ & 62 & 13 & 49 & 59 & 3 & $\begin{array}{l}\text { Refer for } \\
\text { checkup at } \\
\text { clinic. }\end{array}$ \\
\hline BMI & 122 & 32 & 90 & 103 & 19 & $\begin{array}{l}\text { Refer for } \\
\text { checkup at } \\
\text { clinic. }\end{array}$ \\
\hline
\end{tabular}

From all abovementioned activities the abnormal findings were minimal compare to the normal findings. Those with abnormal findings were referred for further management to the clinic.

Table 2: Age categories of respondents.

\begin{tabular}{llllll}
\hline $\begin{array}{l}\text { Age } \\
\text { groups }\end{array}$ & $\begin{array}{l}\text { Neck mas- } \\
\text { sage }\end{array}$ & $\begin{array}{l}\text { Sugar } \\
\text { test }\end{array}$ & $\begin{array}{l}\text { Eye } \\
\text { Test }\end{array}$ & $\begin{array}{l}\text { Blood Pres- } \\
\text { sure }\end{array}$ & BMI \\
\hline $\begin{array}{l}18-25 \\
26-35\end{array}$ & 45 & 64 & 41 & 91 & 77 \\
36 and & 20 & 26 & 13 & 44 & 29 \\
$\begin{array}{l}\text { above } \\
\text { Total }\end{array}$ & 15 & 20 & 8 & 24 & 16 \\
\hline
\end{tabular}

The different age groups as per different health activities provided. The age group 18-25 appears to be the majority within or among the different activities.

\section{Conclusion}

The findings to be shared with all concerned parties being it student committees or academic staff committees. The public demand for health and nutritional information should be taken in consideration when strategies are implemented aimed on improving the nutritional wellbeing of individuals. Students need to be educated and motivated to practice healthy life style habits, (Belaski, 2001).

\section{References}

[1] Belaski, A. College and University students present a challenge for Nutritionist, Journal of America Dietetic Association, 2001: 101:913 [Pub Med] https://doi.org/10.1016/S0002-8223(01)00224-3.

[2] Bimenya, G.S., Byarugaba, W., Kalungi, S., Mayito J., Mugabe, K., Makabayi, R., Ayebare, E., Wanzira, H., \& Muhame, M. (2005). Blood pressure profiles among Makerere University undergraduate students. Makarere Medical School Uganda. Afr Health Sci 2005 June, 5(2): 99-106.

[3] Clinicians' handbook of Preventive service (1998). Put Prevention into action. $2^{\text {nd }}$ edition Washington DC of Public Health an Office of disease Science.

[4] Christensen, LB.2004.Experimental Methodology.Allyn and Bacon: Baston. 
[5] Flegal, K.M., Caroll, M.D., Ogden, C.L \& Johnson, C.L. Prevalence and trends in obesity among US adults, 1999-2000 Journal of the American Medical Association 2002, 288:1723-1727 [PubMed]. https://doi.org/10.1001/jama.288.14.1723.

[6] Garner, L.F., Waghorne, M., \& Anstice, J. (1981). Vision Problems of University Students in New Zealand Part 1 Sociological Survey The Australian Journal of Optometry Volume 64, Issue 5.

[7] Khan, N. Gomathi, K.G., Shehnaz, S.I. and Muttappallymyalil, J. (2012). Diabetes Mellitus-related knowledge among University Students in Ajaman, United Arab Emirates. PMID: 22912923 [PubMed] PMC3413621 Free PMC Article.

[8] Ministry of Health Labor and Welfare, Japan the National Nutrition survey in Japan, 2002. Daiichi publisher 2004.

[9] Oritega R.M., Redondo, M.R., Lopez-Sobaler, A.M., Quintas, M.E., Zamora, M.J., Andres, P., Encinas-Sotillos, A: Association between obesity, breakfast time food habits and intake of energy and nutrients in a group of elderly Madrid residents JAM Coll Nutr 1996,15:6572. https://doi.org/10.1080/07315724.1996.10718566

[10] Pope, H.G., Gruber, A.J., Manweth, B., Bureau, B., de Col, C., Jouvert, R and Hudson, J.L: Body image perception among men in three countries. AMJ Psychiatry 2000, 157: 1297-301. https://doi.org/10.1176/appi.ajp.157.8.1297.

[11] Sakamati, R., Toyama, K., Amamoto, R., Liu, C.J., and Shinfuka, N. (2005). Nutritional knowledge, food habits and health attitude of Chinese university students- a cross sectional study nutritional journal 2005 4:4.

[12] Shantakumari, N. Eideeb. R. \& Gopal, K. (2014). Computer Use and Vision- related problems Among University students in Ajman, United Arab Emirate Ann Med Health Sci Res 2014 Mar-apr, and 4(2): 258-263.

[13] Simao, M. Hayashida, M., dos Santos, C.B., Cesarino, E.J., \& Nogueira, M.S. (2008). Hypertension among undergraduate's students from Lubango, Angola. Revist Latino-Americana de Enfermagem online version ISSN 1518-8345. 